\title{
Statement of Basis/Proposed Plan for the Gunsite 113 Access Road Unit (631-24G)
}

by

E. Palmer

Westinghouse Savannah River Company

Savannah River Site

Aiken, South Carolina 29808

This paper was prepared in connection with work done under the above contract number with the U: $S$. Department of Energy. By acceptance of this paper, the publisher and/or recipient acknowledges the U. S. Government's right to retain a nonexclusive, royalty-free license in and to any copyright covering this paper, along with the right to reproduce and to authorize others to reproduce all or part of the copyrighted paper. 


\section{DISCLAIMER}

This report was prepared as an account of work sponsored by an agency of the United States Government. Neither the United States Government nor any agency thereof, nor any of their employees, makes any warranty, express or implied, or assumes any legal liability or responsibility for the accuracy, completeness, or usefulness of any information, apparatus, product, or process disclosed, or represents that its use would not infringe privately owned rights. Reference herein to any specific commercial product, process, or service by trade name, trademark, manufacturer, or otherwise does not necessarily constitute or imply its endorsement, recommendation, or favoring by the United States Government or any agency thereof. The views and opinions of authors expressed herein do not necessarily state or reflect those of the United States Government or any agency thereof.

This report has been reproduced directly from the best available copy.

Available to DOE and DOE contractors from the Office of Scientific and Technical Information, P.O. Box 62, Oak Ridge, TN 37831; prices available from (615) 576-8401.

Available to the public from the National Technical Information Service, U.S. Department of Commerce, 5285 Port Royal Road, Springfield, VA 22161. 


\section{DISCLAIMER}

Portions of this document may be illegible electronic image products. Images are produced from the best available original document. 
United States Department of Energy

Savannah River Site

\section{STATEMENT OF BASIS/PROPOSED PLAN FOR THE GUNSITE 113 ACCESS ROAD UNIT (631-24G) (U)}

WSRC-RP-96-218

Revision 1 (changes in boldface)

July 8,1996

Prepared by:

Westinghouse Savannah River Company

Savannah River Site

Aiken, South Carolina 29808

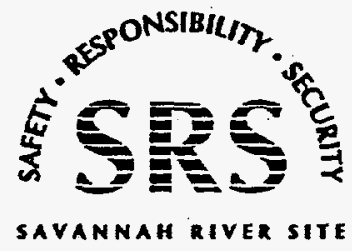




\section{Table of Contents}

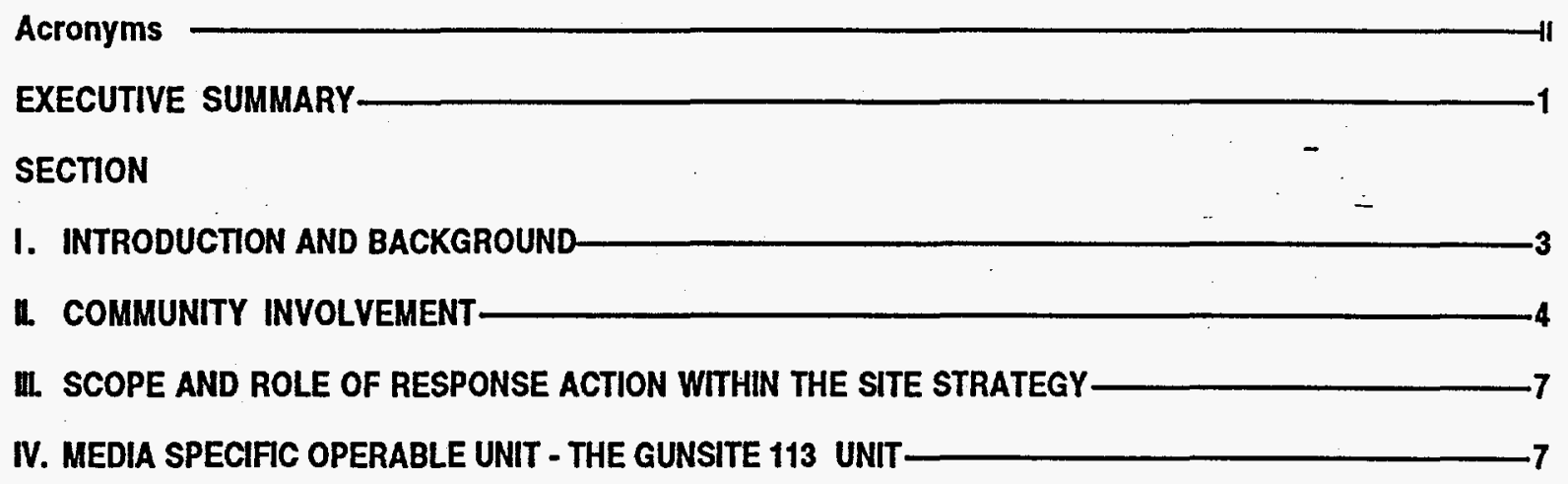

IVA. Unit Description and Location, Unit History, and Media Assessment-_ 7

IVB. Operable Unit Risks-_ 10

V. DESCRIPTION OF THE "NO ACTION" PREFERRED ALTERNATIVE-

REFERENCES- 11

List of Figures

1. Location of the Gunsite 113 Access Road Unit in Relation to Major $-5$ Savannah River Site Facilities

2. Layout of the Gunsite 113 Access Road Unit 6

\section{Appendix}

A. Glossary $-A \cdot 1$ 


\section{Acronyms}

BRA Baseline Risk Assessment

CERCLA Comprehensive Environmental Response, Compensation, and Liability Act, 1980

DOE U.S. Department of Energy

EPA U.S. Environmental Protection Agency

FFA Federal Facility Agreement

HI Hazard Index

MCLG Maximum Contaminant Level Goal

RBC Risk-Based Concentration

RCRA Resource Conservation and Recovery Act, 1976

RFI/RI RCRA Facility Investigation/Remedial Investigation

ROD Record of Decision

SCDHEC South Carolina Department of Health and Environmental Control

SRS Savannah River Site

SSL Soil Screening Level

WSRC Westinghouse Savannah River Company 


\section{EXECUTIVE SUMMARY}

This Statement of Basis/Proposed Plan for the Gunsite 113 Access Road Unit is issued by the U.S. Department of Energy (DOE), the lead agency for the Savannah River Site (SRS) remedial activities, with concurrence by the U.S. Environmental Protection Agency (EPA) - Region IV, and the South Carolina Department of Health and Environmental Control (SCDHEC).

The purpose of this plan is to describe the preferred remedial alternative for addressing the Gunsite 113 Access Road Unit located at SRS in Aiken, SC, and to provide an opportunity for public input into the remedial action selection process. Section 117(a) of the Comprehensive Environmental Response, Compensation, and Liability Act (CERCLA) and R.6179.124 of the South Carolina Hazardous Waste Management Regulations (SCHWMR) require publication of a notice of the proposed remedial action(s) (i.e., the Statement of Basis/Proposed Plan).

SRS manages certain waste materials which are regulated under RCRA, a comprehensive law, requiring responsible management of hazardous waste. RCRA 3004(u) requires that releases from solid waste management units be investigated and remediated as necessary. The Gunsite 113 Access Road Unit is a solid waste management unit regulated under RCRA 3004(u).

The Gunsite 113 Access Road Unit is approximately 24.4 meters (80 feet long) and 15.2 meters (50 feet) wide, and is located in the northeast corner and on the boundary of SRS. The unit is a grassy area of weeds and small trees containing several small mounds of dirt and asphalt covered with a thick layer of pine straw, brush, and young trees.

During the period 1955 to 1960 at SRS, the U.S. Army established various gunsites for anti-aircraft artillery gun emplacements to defend SRS in the event of an air attack. Gunsite 113 was one of those emplacements.

In the mid 1980s, sparse vegetation, dead trees, and small mounds of soil were discovered on a portion of the road leading to Gunsite 113. This area became the Gunsite 113 Access Road Unit. The unit was used as a disposal area for spoil dirt and/or road construction debris. There is no documentation or record of any hazardous substance management, disposal, or any other type of waste disposal at this unit. There is no evidence of any burning, excavation, or recent disposal activities having occurred in this area or that disposal activities were more widespread.

The results of the Resource Conservation and Recovery Act (RCRA) Facility Investigation/CERCLA Remedial Investigation (RFI/RI) Report (WSRC, 1996) indicate that the Gunsite 113 Access Road Unit poses no impact to human health or the environment. There is no evidence of contamination and no sign of any buried materials at this unit. Analytical results of soil samples collected in 1990 indicate that all substances detected are at concentrations below EPA risk-based concentration levels.

Since the arsenic detected is not from the unit, the source of the arsenic will be evaluated on a sitewide scale during the Soil Background Study.

Based on the results of the RFI/RI Report (WSRC, 1996), DOE, EPA, and SCDHEC recommend that no remedial action be performed at this unit. There is no waste to treat and therefore, no institutional or engineering controls are required. The proposed no action alternative is intended to be the final action. No cleanup activities and no cost(s) would be involved. 
Community involvement in the remedial alternative selection review process for the Gunsite 113 Access Road Unit is strongly encouraged. Section II includes SRS contact information to request a public meeting, to obtain additional information about this proposed plan, or to submit comments. All submitted comments will be reviewed and considered prior to a final decision. A Responsiveness Summary will be prepared to address significant issues raised during the public comment period. The summary will be made available in the Record of Decision (ROD) and with the final RCRA permit. The ROD and RCRA permit document the final decision for the unit. 


\section{SECTION I. INTRODUCTION AND BACKGROUND}

\section{Introduction}

This Statement of Basis/Proposed Plan for the Gunsite 113 Access Road Unit is issued by DOE, which is the lead agency for SRS remedial activities, with concurrence by EPA and SCDHEC. The purpose of this plan is to describe the preferred alternative for addressing the Gunsite 113 Access Road Unit located in the northeast comer of SRS near Aiken, SC, and to provide for public involvement in the decision-making process.

SRS manages certain waste materials which are regulated under RCRA, a comprehensive law, requiring responsible management of hazardous waste. RCRA 3004(u) requires that releases from solid waste management units be investigated and remediated as necessary. The Gunsite 113 Access Road Unit is a solid waste management unit regulated under RCRA 3004(u).

CERCLA public participation requirements are listed in Sections 113 and 117 of CERCLA. These requirements include establishment of an Administrative Record File that documents the selection of remedial alternatives and allows for review and comments by the public regarding those alternatives (see Section II). The Administrative Record File must be established "at or near the facility at issue." The SRS Public Involvement Plan (DOE, 1994), is designed to facilitate public involvement in the decision-making process for permitting, closure and the selection of remedial alternatives. Section 117(a) of CERCLA requires publication of a notice of any proposed remedial action and provides the public an opportunity to participate in the selection of a remedial action.
RCRA provides opportunities for the public to comment on draft permit modifications. Public participation requirements are also listed in SCHWMR R.61-79.124 and require publication of the draft permit modifications. SCHWMR R.6179.124 requires that a brief description and response to all significant comments be made available to the public as a part of the Administrative Record. The preferred alternative proposed in this Statement of Basis/Proposed Plan is also being proposed as a draft permit modification under RCRA. Therefore, any comments received on this Statement of Basis/Proposed Plan will also be applicable to the draft RCRA permit modification, proposing the same remedy for this waste unit.

This Statement of Basis/Proposed Plan is a summary of the Administrative Record File leading to selection of the preferred alternative. The proposed plan presents the preferred alternative and the rationale for selecting that alternative. Community involvement in consideration of this evaluation of alternatives for the Gunsite 113 Access Road Unit is strongly encouraged. All submitted comments will be reviewed and considered.

Following the public comment period, a Responsiveness Summary will be prepared to address significant issues raised during the comment period. The Responsiveness Summary will be made available with the final RCRA permit modification and the ROD. 
The final selection of the remedial alternative under RCRA will be in the form of a final permit modification decision which is made by SCDHEC. The final selection of the remedial altemative that will satisfy the FFA requirements will be made by $\mathrm{DOE}$, in consultation with EPA and SCDHEC, only after the public comment period has ended and all comments submitted have been reviewed and considered.

\section{Background}

SRS occupies approximately 310 square miles of land adjacent to the Savannah River, principally in Aiken and Barnwell Counties of South Carolina. SRS is a secured U.S. Government facility with no permanent residents. SRS is located approximately 25 miles southeast of Augusta, GA, and 20 miles south of Aiken, SC. Figure 1 shows the location of the Gunsite 113 Access Road Unit in relation to other facilities at SRS and Figure 2 shows the layout of the unit with sample locations.

\section{SECTION II. COMMUNITY INVOLVEMENT}

This Statement of Basis/Proposed Plan summarizes information from the documents listed in the References Section of this proposed plan. These unabridged documents are part of the FFA Administrative Record File, which is available for review by the public at the following locations:

\section{U.S. Department of Energy}

Public Reading Room

Gregg-Graniteville Library

University of South Carolina-Aiken

171 University Parkway

Aiken, SC 29801

(903) 641-3465
Thomas Cooper Library

Government Documents Department

University of South Carolina

Columbia, SC 29208

(803) 777-4866

Similar information is available through the repositories listed below:

Reese Library

Augusta State University

2500 Walton Way

Augusta, GA 30910

(706) $737-1744$

Asa H. Gordon Library

Savannah State University

Tompkins Road

Savannah, GA 31404

(912) 356-2183

The RCRA Administrative Record File for SCDHEC is available for review by the public at the following locations:

The South Carolina Department of Health and Environmental Control

Bureau of Solid and Hazardous Waste Management

8901 Farrow Road

Columbia, South Carolina 29203

(803) 896-4000

Lower Savannah District

Environmental Quality Control Office

215 Beaufort St., NE

Aiken, SC 29802

(803) 648-9561

The public will be notified of a public comment period by mailing the SRS Environmental Bulletin, a newsletter sent to approximately 3500 citizens in South Carolina and Georgia, and through the Aiken Standard, the Allendale Citizen Leader, the Barnwell People-Sentinel, the State, and the Augusta Chronicle newspapers. The public comment period will also be announced on local radio stations. 


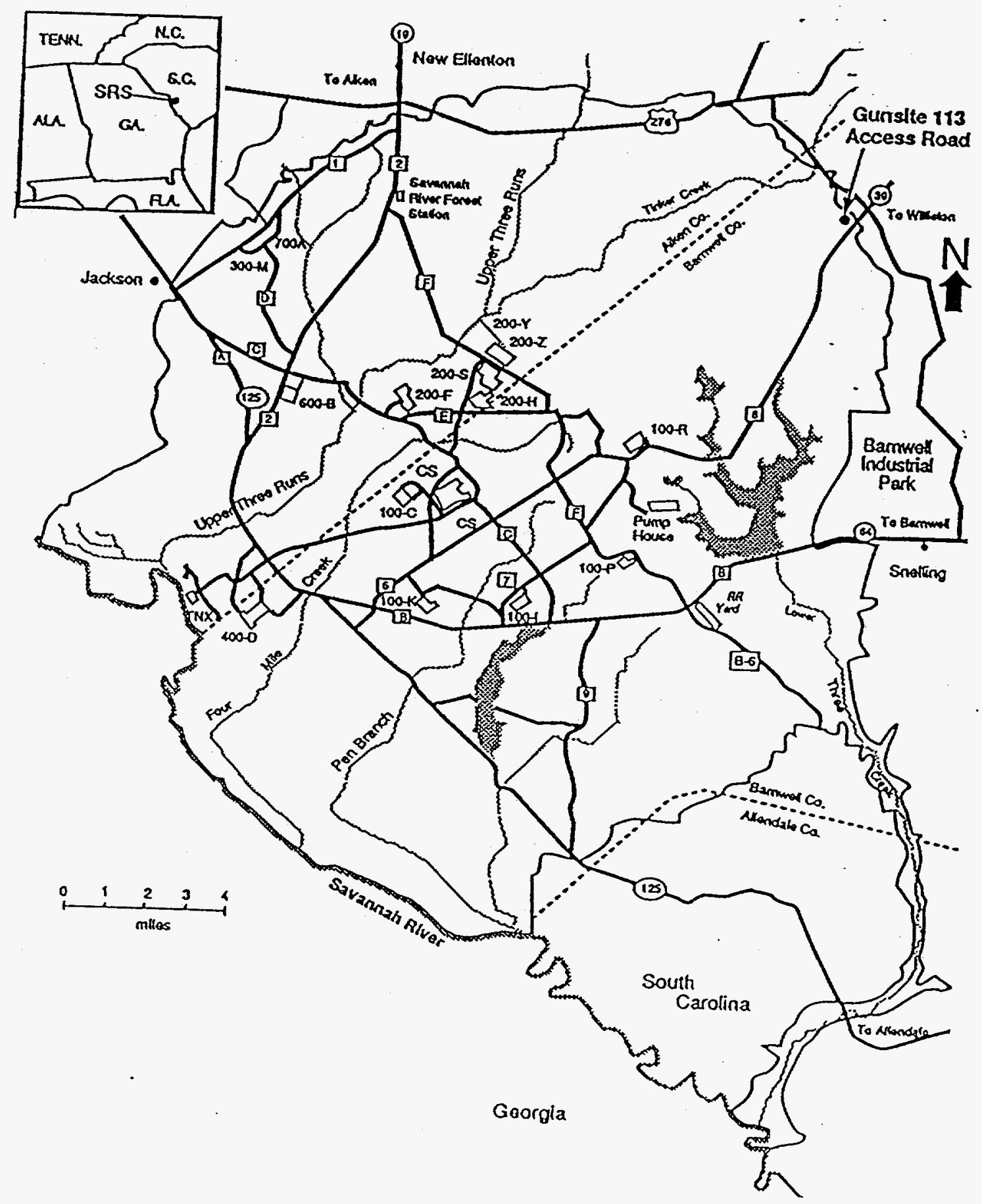

Figure 1. Location of the Gunsite 113 Access Road Unit in Relation to Major SRS Facilities 
Pine

Forest

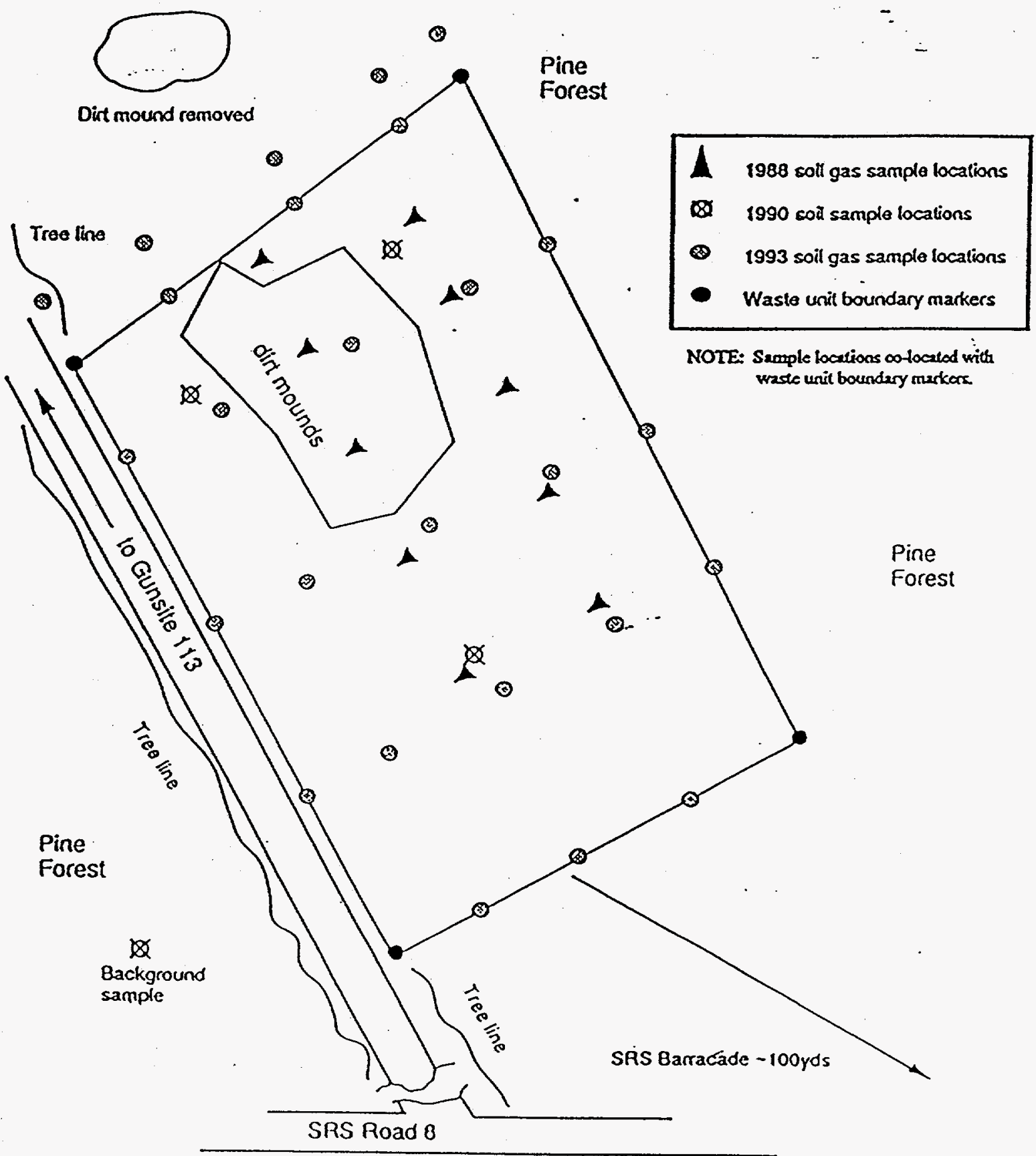

Figure 2. Layout of the Gunsite 113 Access Road Unit With Sample Locations 
DOE will provide an opportunity for a public meeting during the public comment period, if significant interest is expressed. The public will be notified of the date, time, and location. At the meeting, the proposed action will be discussed and questions about the action will be answered.

To request a public meeting during the comment period, to obtain more information concerning this Statement of Basis/Proposed Plan, or to submit written comments, contact one of the following:

\section{A. Flora}

Public Involvement

Westinghouse Savannah River Company

Savannah River Site

Building 730-2B

Aiken, SC 29808

(803) 952-6852

The South Carolina Department of Health and Environmental Control

Bureau of Solid and Hazardous Waste Management

8901 Farrow Road

Columbia, South Carolina 29203

(803) 896-4000

Following the comment period, a ROD will be signed and a final decision for the RCRA Permit will be issued. The ROD and RCRA Permit will detail the remedial alternative chosen for the Gunsite 113 Access Road Unit and will include responses to oral and written comments received during the public comment period in the Responsiveness Summary.

\section{SECTION III. SCOPE AND ROLE OF RESPONSE ACTION WITHIN THE SITE STRATEGY}

The Gunsite 113 Access Road Unit is an operable unit located within the Upper Three Runs Watershed. In addition to the Gunsite 113 Access Road unit, there are many operable units within the watershed. All the source control and groundwater operable units located within the watershed will be evaluated to determine their impacts, if any, to the associated streams and wetlands.

SRS will manage all source control units to prevent impact to the watershed. Upon disposition of all source control and groundwater operable units within the watershed, a final comprehensive ROD for the Upper Three Runs Watershed will be pursued.

The field investigations and soil sampling conducted during 1990 indicated that there is no impact from the Gunsite 113 Access Road Unit to the groundwater. However, the source of the arsenic will be evaluated on a sitewide scale during the implementation of the Soil Background Study.

\section{SECTION .IV. MEDIA SPECIFIC OPERABLE UNIT - THE GUNSITE 113 UNIT}

Section IVA. Unit Description and Location, Unit History, and Media Assessment

\section{Unit Description and Location}

The Gunsite 113 Access Road Unit is located in the northeast corner of SRS, adjacent to the access road leading to Gunsite 113, and is approximately 91.5 meters (300 feet) east of where SRS Road 8 crosses the SRS facility boundary (see Figure 1).

The Gunsite 113 Access Road Unit covers an area of approximately 370 square meters $(4,000$ square feet) and is a grassy area of weeds and small trees within a mature pine forest. It consists of several small mounds of dirt and asphalt adjacent to the grassy area and several downed pine trees. The mounds of dirt/debris are covered with a thick layer of pine straw, brush, and young trees. The grassy open area, east of the 
mounds, was identified as the area most likely impacted by possible waste disposal activities. The area contains several dead trees that have fallen down. The terrain is flat, with an elevation of about 320 feet above mean sea level. There are no major drainage features nearby. The nearest surface water body is a small unnamed creek located approximately 1.3 kilometers (0.8 miles) southeast which feeds into Rosemary Creek, a tributary of Salkehatchie River. The water table is approximately 60 feet below ground surface.

\section{Unit History}

During the period from 1955 to 1960 , to defend SRS in the event of an air attack, the U.S. Army established onsite anti-aircraft artillery gun emplacements $(75 \mathrm{~mm}$ and $90 \mathrm{~mm}$ guns) at several locations near the perimeter of SRS. Gunsite 113 was one of those emplacements.

In the mid 1980s, sparse vegetation, dead trees (stressed vegetation), and small mounds of soil were discovered on a portion of the road leading to Gunsite 113 . This area, encompassing the portion of the road, became the Gunsite 113 Access Road Unit.

The area appears to have been used as a surface disposal area for spoil dirt and/or road construction debris. There is no documentation or record of any hazardous substance management, disposal, or any other type of waste disposal at this unit. There is no evidence that any recent disposal activities have occurred in this area or that disposal activities were more widespread. Also, there is no evidence of any burning or excavation at this waste unit.

There are no structures of any type located at or near the Gunsite 113 Access Road Unit. The only nearby man-made features are SRS Road 8, which passes within 91.5 meters ( 300 feet) east of the unit and the unpaved access road to Gunsite 113, which passes by the unit.

\section{Media Assessment}

The RFI/RI Plan (WSRC, 1990) and RFI/RI Report (WSRC, 1996) contain detailed information and analytical data for all the investigations conducted and samples taken in the media assessment of the Gunsite 113 Access Road Unit. These documents are available in the Administrative Record File (see Section II of this document).

Preliminary investigations pertaining to the Gunsite 113 Access Road Unit were conducted in March and April 1988. The investigations consisted of ten soil samples and ten soil gas samples. The soil samples showed trace levels of 1,2 dichloroethylene $(<11 \mathrm{mg} / \mathrm{kg}$ but $>3$ $\mathrm{mg} / \mathrm{kg}$ ). The soil gas samples contained only low levels of light hydrocarbons ( $<2500 \mathrm{ppb}$ methane). However, these levels were within the range of natural background levels.

In March 1989, a ground penetrating radar survey was conducted. The survey indicated that there was no evidence of any buried or underground objects in the area.

\section{SOILS}

During 1990,13 soil samples were collected from four borehole locations. Three boreholes were drilled within the Gunsite 113 Access Road Unit and one outside the unit for background sampling. The soil samples were taken at different depth ranges: 0.9-1.5 meters (3-5 feet); 2.4 3.05 meters (8-10 feet); 3.9-4.6 meters (1315 feet); and 5.5-6.1 meters (18-20 feet) below the ground surface. The samples were sent to an offsite laboratory for analysis and were analyzed in accordance with EPA Contract Laboratory Program approved protocols. The only hazardous substances which were detected and exceeded their respective unit-specific background levels were three metals (arsenic, chromium, and lead). Total cyanide 
and trace levels of tin, vanadium, and zinc were also detected. Although no unitspecific background data were obtained for these constituents, their concentrations were below EPA risk-based concentration (RBC) levels.

\section{Additional Investigations}

In 1993, SRS performed an additional ground penetrating radar survey for the purpose of making a final determination of any buried waste or any other debris at the Gunsite 113 Access Road Unit. Eleven lines totaling about 305 meters (1,000 feet) were acquired. An additional soil gas survey was also completed in 1993. A total of 30 sample locations were established and samples were collected at each location (see Figure 2).

The ground penetrating radar survey confirmed that no buried objects, trenches, or burial pits exist at the Gunsite 113 Access Road Unit. The levels of volatile and diesel-range organics observed in the soil gas survey were approximately $200 \mathrm{ppbv}$ methane. The concentration levels were consistent with the normal background levels associated with the natural decay of plant and animal matter.

In summary, data collected during the field investigations conducted in 1990 and 1993 found no evidence of any buried hazardous materials. The analytical results of 1990 soil sampling revealed that three metals (arsenic, chromium, and lead), and cyanide were detected at levels slightly exceeding unitspecific background levels.

The maximum concentration of arsenic detected was $1.8 \mathrm{mg} / \mathrm{kg}$ which exceeds EPA risk-based concentration level of 0.43 $\mathrm{mg} / \mathrm{kg}$ for soil ingestion, residential scenario. However, the arsenic detected at the site is probably not from the unit but part of the sitewide situation associated with pre-SRS farming activities. The source of the arsenic is being evaluated on a sitewide scale as part of the Soil Background Study.

The maximum concentration of chromium detected was $24.3 \mathrm{mg} / \mathrm{kg}$. Compared to the EPA risk-based concentration (RBC) level (390 $\mathrm{mg} / \mathrm{kg}$, residential), the concentration of chromium is low. However, the concentration of chromium $(24.3 \mathrm{mg} / \mathrm{kg})$ was detected in the soil sample collected from the 2.4-3.05 meters (8-10 feet) depth interval. This concentration exceeds EPAs generic soil screening level (SSL) for migration from soil to groundwater which is $19 \mathrm{mg} / \mathrm{kg}$. Also the EPA site specific SSL for transfer of chromium from soil to groundwater for the 2.4-3.05 meters (8-10 feet) depth interval is $13.5 \mathrm{mg} / \mathrm{kg}$. Hence, the maximum concentration of chromium detected exceeds the EPA's SSLs.

Because the chromium concentration detected exceeded both SSLs, it was decided to evaluate further for any potential unacceptable risk to a future resident that may be associated with chromium's migration from soil to groundwater. To determine the potential risk, a chromium leachability model was studied using site specific standard groundwater model equations. The model estimated that the chromium concentration in the groundwater would peak at a concentration of $0.18 \mathrm{mg} / \mathrm{L}$ in approximately 1,707 years. The calculated concentration is approximately $0.08 \mathrm{mg} / \mathrm{L}$ higher than the $0.10 \mathrm{mg} / \mathrm{L}$ accepted maximum contaminant level goal (MCLG) for chromium VI, but is equivalent to the chromium VI risk-based concentration ( $\mathrm{RBC})$ for tap water $(0.18$ $\mathrm{mg} / \mathrm{L}$ ) resulting in a hazard index (HI) equal to 1. For chromium III which has an $\mathrm{RBC}$ value of $37.0 \mathrm{mg} / \mathrm{L}$, the $\mathrm{HI}$ calculated was $4.9 \times 10^{-3}$.

These results for chromium are considered to be conservative since chromium was detected in only one sample at the 2.4-3.05 meters (8-10 feet) depth interval and peak concentration in the groundwater would be achieved in nearly 2,000 years. Additionally, 
soil samples collected in the source borehole at the 0.9-1.5 meters (3-5 feet), 3.9-4.6 meters (13-15 feet), and 5.5-6.1 meters (18-20 feet) depth intervals did not detect chromium.

The maximum concentration of lead was $4.8 \mathrm{mg} / \mathrm{kg}$. The concentration is significantly lower than the EPA risk-based concentration level $(400 \mathrm{mg} / \mathrm{kg}$, residential). The maximum concentration of cyanide detected $(2.2 \mathrm{mg} / \mathrm{kg})$ is also well below the EPA risk-based concentration level (1,600 mg/kg, residential).

The results indicate that the concentrations of all hazardous substances analyzed were near or below naturally occurring background levels and/or below EPA riskbased concentrations. Hence, there are no chemicals of concern (COCs) and there is no impact to human health or the environment from Gunsite 113 Access Road Unit.

\section{Groundwater and Ecological Investigations}

Since the ground penetrating radar surveys and field investigations conducted in 1988 and 1989 and soil sampling conducted in 1990 showed no sign of any hazardous waste disposal at this unit, groundwater and ecological investigations were not conducted.

\section{Section IVB. Operable Unit Risks}

\section{Human Health Risk Assessment}

A review of the analytical data for the Gunsite 113 Access Road Unit indicates that the data are of sufficient quality for use in the unit risk assessment evaluation. An evaluation was conducted to estimate the human health and environmental problems that could result from the no action alternative. The results indicate that the concentrations of all hazardous materials analyzed were below EPA risk-based concentrations.
Based on the available data, there are no COCs for evaluation in a CERCLA baseline risk assessment (BRA), and hence, there is no determinable risk associated with the Gunsite 113 Access Road Unit.

\section{Ecological Risk Assessment}

Based on the physical and analytical data pertaining to this unit, there is no compelling evidence that hazardous materials were managed or disposed at the Gunsite 113 Access Road Unit. Therefore, it is reasonable to conclude that this unit presents no significant ecological risk. A further detailed ecological risk assessment and characterization is not warranted.

\section{SECTION V. DESCRIPTION OF THE "NO ACTION" PREFERRED ALTERNATIVE}

\section{Section VA. Alternatives Considered for Evaluations}

Based on the unit characterization and risk assessment, the Gunsite 113 Access Road Unit poses no risk to human health and the environment. Therefore, the unit requires no cleanup activities and the no action alternative is recommended for this unit. No other alternatives were considered for evaluation.

The no action alternative means that no remedial action will be performed at the Gunsite 113 Access Road Unit. There is no waste to treat, no institutional or engineering controls are required, and there are no applicable or relevant and appropriate requirements (ARARs). Because no further action would be taken, the Gunsite 113 Access Road Unit would remain in its present condition. No costs would be involved for this action.

Since the Gunsite 113 Access Road Unit poses no risk to human health or the environment and no action is warranted at this unit, it satisfies CERCLA criteria. The 
no action alternative will be the final action for the Gunsite 113 Access Road Unit. This solution is meant to be permanent and effective in both the long and short terms.

This Statement of Basis/Proposed Plan provides for community involvement through a document review process and a public comment period. Public input will be documented in the responsiveness summary section of the ROD.

\section{REFERENCES}

DOE (U.S. Department of Energy), 1994, Public Involvement, A Plan for the Savannah River Site, Savannah River Operations Office, Aiken, SC.

Federal Facility Agreement, 1993, Federal Facility Agreement for the Savannah River Site, Administrative Docket No., 89-05-FF, (Effective Date: August 16, 1993).

Looney, B. B. et al., 1988, Soil Gas Surveys at Selected Potential Waste Sites at the Savannah River Site, DPST-88-619, E. I. du Pont de Nemours and Company, Savannah River Laboratory, Aiken, SC.

WSRC, 1990, RCRA Facility Investigation/Remedial Investigation Plan for the Gunsite 113 Access Road Unit, WSRC-RP-90-996, Westinghouse Savannah River Company, Aiken, SC.

WSRC, 1996, RCRA Facility Investigation/Remedial Investigation Report for the Gunsite 113 Access Road Unit (U), WSRC-RP-95-359, Rev 1, Westinghouse Savannah River Company, Aiken, SC. 


\section{APPENDIX A. GLOSSARY}

Administrative Record File: A file that is maintained and contains all information used to make a decision on the selection of response action under the Comprehensive Environmental Response, Compensation, and Liability Act. This file is to be available for public review, and a copy is to be established at or near the Site, usually at one of the information repositories. Also, a duplicate file is held in a central location, such as a regional or state office.

Applicable or Relevant and Appropriate Requirements (ARARs): ARARs refer to the Federal and state requirements that a selected remedy will attain. These requirements may vary from site to site.

Baseline Risk Assessment (BRA): An analysis of the potential adverse health effects (current or future) caused by hazardous substance release from a site in the absence of any actions to control or mitigate these releases.

Characterization: The compilation of all available data about waste units to determine the rate and extent of contaminant migration resulting from the waste site, and the concentration of any contaminants that may be present.

Chemicals of Concern (COCs): Site and media specific, man-made and naturally occurring inorganic and organic chemicals, pesticides, and radionuclides detected at a unit during the RFI/RI and found to contribute significantly to a pathway having a hazard quotient greater than 1.0 or a carcinogenic risk exceeding $1 \times 10^{-6}$ during the BRA.

Comprehensive Environmental Response, Compensation, and Liability Act (CERCLA), 1980: A federal law passed in 1980 and modified in 1986 by the Superfund Amendments and
Reauthorization Act. The Acts created a special tax that goes into a Trust Fund, commonly known as Superfund, to investigate and cleanup _abandoned or uncontrolled hazardous waste sites.

Exposure: Contact of an organism with a chemical or physical agent. Exposure is quantified as the amount of the agent available at the exchange boundaries of the organism (e.g., skin, lungs, digestive tract) and available for absorption.

Federal Facility Agreement (FFA): A legally binding agreement between regulatory agencies (EPA and SCDHEC) and regulated entities (DOE) that sets standards and schedules for compliance with environmental laws.

Ground Penetrating Radar (GPR): A technique involving the recording and displaying of reflected radio frequency energy to evaluate soil, structures, and buried waste objects.

Magnetometer: A device used to locate buried metallic objects which create a measurable disturbance in the magnetic field of the earth.

Media: A pathway through which contaminants are transferred. Five media by which contaminants may be transferred are: groundwater, soil, surface water, sediments, and air.

Microgram per Kilogram: A unit of measure of concentration equivalent to the weight/mass ratio expressed as $\mathrm{ug} / \mathrm{kg}$ or parts per billion (ppb).

National Priorities List (NPL): Formal listing of the nation's worst contaminated sites, as established by the Comprehensive Environmental Response, Compensation, and Liability Act. 
Operable Unit: A discrete action taken as one part of an overall site cleanup. The term is also used in EPA guidance documents to refer to distinct geographic areas or media-specific units within a site. A number of operable units can be used in the course of a cleanup.

Parts per Million: A unit of measure of concentration equivalent to the weight/volume or weight/mass ratio expressed as $\mathrm{mg} / \mathrm{L}$ or $\mathrm{mg} / \mathrm{kg}$, respectively.

Record of Decision (ROD): A legal document that describes the final remedial actions selected for a Superfund site, why the remedial actions were chosen and not others, how much they will cost, and how the public responded to the proposed remedial actions.

Resource Conservation and Recovery Act (RCRA), 1976: What is commonly referred to as RCRA is an amendment to the first pieces of federal solid waste legislation called the Solid Waste Disposal Act of 1965. RCRA was amended in 1980 and on November 8, 1984 by the Hazardous and Solid Waste Amendments (HWSA).
Resource Conservation and Recovery Act (RCRA) Facility Investigation/Remedial Investigation (RFI/RI): Investigation conducted at a waste site to determine the extent and magnitude of a hazardous substance release from the waste site to any environmental media. Information generated - in the investigation is utilized in the BRA; the results of the investigation are documented in the RFI/RI Report.

Responsiveness Summary: A summary of oral and/or written public comments received during the proposed plan comment period and includes responses to those comments. The Responsiveness Summary is a key part of the ROD, documenting community concerns.

Statement of Basis/Proposed Plan (PP): A legal document that provides a brief analysis of remedial altematives under consideration for the site/operable unit and proposes the preferred alternative. It actively solicits public review and comment on all alternatives under consideration. 